África (São Paulo, 1978, Online), São Paulo, n. 42, p. 39-60, 2021

http://dx.doi.org/

\title{
A música como forma de resistência em Angola: Da música anticolonial ao rap de intervenção
}

Francisco Carlos Guerra de Mendonça Júnior'

Biografia: Doutor em Ciências da Comunicação na Universidade de Coimbra, é professor de jornalismo da Universidade Federal do Cariri (UFCA). É mestre em Comunicação e Jornalismo pela Universidade de Coimbra e formado em Comunicação Social - Jornalismo e Radialismo pela Universidade Federal do Rio Grande do Norte. Possui também MBA em administração e marketing esportivo pela Faculdade Nordeste.

Pesquisa realizada com apoio da Capes no Programa de Doutoramento Pleno no Exterior - Processo BEX 99999.002257/2015-07

\section{A música como forma de resistência em Angola: Da música anticolonial ao rap de intervenção}

A música teve papel fundamental na luta anticolonial em Angola, desde o surgimento do grupo Ngola Ritmos na década de 1940, que expandia os ideais nacionalistas. Durante as décadas seguintes, vários grupos surgiram, cantando em prol dos movimentos de libertação. A música de cunho político, no entanto, passou a ser silenciada, após uma chacina ocorrida em 27 de maio de 1977, em que três músicos populares estiveram entre as milhares de vítimas. Após o fato, só existiram canções de cunho político gravadas por 
FRANCISCO CARLOS GUERRA DE MENDONÇA JÚNIOR A música como forma de resistência em Angola: Da música anticolonial ao rap de intervenção

angolanos na diáspora. $\mathrm{O}$ retorno das músicas politizadas, produzidas no país, se dá na década de 1990, com o surgimento do rap. Atualmente, vários rappers denunciam o regime do MPLA e alguns participam de manifestações de rua. Essas ações já resultaram em várias prisões a rappers.

Palavras-chave: Música, intervenção, história, Angola, rap.

\section{Music as a form of resistance in Angola: From anticolonial music to intervention rap}

Music played a key role in the anticolonial struggle in Angola, since the emergence of the Ngola Ritmos group in the 1940s, which expanded nationalist ideals. Over the following decades, various groups emerged, singing for the liberation movements. The political music, however, was silenced after a massacre on May 27, 1977, where three popular musicians were among the thousands of victims. After the fact, there were only political songs recorded by Angolans in the diaspora. The return of the politicized songs produced in the country occurred in the 1990s, with the emergence of rap. Currently, several rapper denounce the MPLA regime and some participate in street demonstrations. These actions have already resulted in several arrests of rappers.

Keywords: Music, intervention, history, Angola, rap.

INTRODUÇÃO

A música tem um papel primordial na história política de Angola. Foi um grupo musical, o Ngola Ritmos, que impulsionou de forma inédita o espírito revolucionário pró-independentista sobre o povo angolano, na década de 1940, levando aos bairros periféricos o desejo de lutar contra o colonizador, ação que também inspirou outros artistas. Esse grupo fomentou ainda uma forma de imprensa clandestina, que divulgava panfletos com mensagens anticolonialistas.

O Ngola era formado por membros do Movimento Pela Libertação de 
Angola (MPLA), a frente de libertação que tinha predominância na capital Luanda e que em 1975 foi reconhecida como único grupo político a conquistar a independência do país, apesar das lutas do FNLA e da UNITA em também combaterem o colonizador. O FNLA também viu a importância da música para estimular o espírito revolucionário e lançou vinil com seus artistas. A música ainda foi importante para divulgar os ideais do MPLA em vozes como as de Artur Nunes, Urbano de Castro e David Zé, que se tornaram populares em impulsionar os ideais revolucionários pró-independência, mas que foram assassinados por ordem do próprio presidente do MPLA e primeiro presidente do país, Agostinho Neto, dois anos depois da conquista da independência.

Diante disso, o objetivo deste artigo é analisar o papel histórico da música como ferramenta de contestação política em Angola, tanto na luta pela independência, como na atualidade. Entre os períodos destacados, há um silenciamento de mais de duas décadas de músicas com esse viés, iniciado na chacina de milhares de pessoas em 27 de maio de 1977 e finalizado com a expansão da música rap como ferramenta política, a partir do final da década de 1990. Isso porque as mortes de Artur Nunes, Urbano de Castro e David Zé resultaram no medo em produzir músicas questionando o quadro político de Angola. As exceções foram apenas de artistas que viviam no exterior.

Este artigo ainda mostra que os artistas interventivos da atualidade também sofrem com repressões, como perseguição, prisões, ameaças e até mortes. As vítimas são tanto os artistas, como os seus fãs. Apesar disso, o gênero rap impulsiona as manifestações sociais e resgata a história de músicos do passado, que também lutaram pela libertação de Angola, como será visto ao longo do artigo.

NGola RitMOS: GRUPO PIONEIRO NA INTERVENÇÃO SOCIAL

As canções com críticas sociais surgiram na década de 1940, com a formação do grupo Ngola Ritmos, fundado por Liceu Vieira Dias. O grupo reivindicava uma identidade angolana e, de acordo com Mormaan (2010), questionava o discurso lusotropicalista proclamado pelo Império Português².

2 De acordo com Cunha (1998), o lusotropicalismo era um discurso embasado por alguns acadêmicos e proclamado durante o regime salazarista, que buscava reforçar a propaganda do Estado Novo, para fomentar 
FRANCISCO CARLOS GUERRA DE MENDONÇA JÚNIOR A música como forma de resistência em Angola: Da música anticolonial ao rap de intervenção

Através do lusotropicalismo, Portugal tentava mostrar que existia a possibilidade de união entre o colonizador e o colonizado, diminuindo as suas diferenças, mostrando uma virtude desse Império, em relação aos demais países europeus. Todavia, o Ngola Ritmos denunciava as diferenças entre os portugueses e africanos, bem como entre os moradores de bairros com maior estrutura, como a baixa, e os musseques. Macêdo (2008, p. 115) afirma que "musseque inicialmente designava os terrenos agrícolas arenosos situados fora da orla marítima, passando mais tarde a nomear os bairros pobres situados nas franjas da cidade de Luanda".

De acordo com Mormaan (2010), apareceram vários músicos em Angola, após o surgimento do Ngola Ritmos. A maioria deles narrava o cotidiano e as preocupações, tanto familiares, como sociais. Por viverem em condições precárias, eles narravam o sofrimento que vivenciavam em seu cotidiano. Os artistas não tinham intenções claramente políticas, porém, como viviam em uma realidade de dificuldade e aspiravam por melhorias, essas músicas se tornavam políticas, o que incomodava o Império Português, que buscava formas de restringir, como, por exemplo, através da censura.

A música foi um dos traços mais importantes para a construção da identidade angolana, a chamada angolanidade, sobretudo devido ao resgate das línguas locais nas canções. Os artistas muitas vezes aprendiam o quimbundo apenas na fase adulta, para cantarem nessa língua, porém foram alfabetizados em português. Tratava-se de uma forma de contrapor a um apagamento identitário, provocado pelo Estatuto do Indigenato, implementado em 1930 e que dividia o povo colonizado em indígena e assimilado cultural (MENESES, NASCIMENTO). O indígena era o nativo local que não tinha qualquer direito social e mantinham os hábitos e costumes locais, já o assimilado conseguia aceder a empregos formais e algumas estruturas da colônia, desde que adotasse hábitos culturais portugueses, entre esses, o uso da língua portuguesa.

Segundo Mormaan (2010) a negação da influência do colono contribuía para a formação dessa identidade africana. Uma das formas dessa

a aceitação ou o reforço da permanência dos portugueses nas colônias, "através da promoção, valorização e organização das manifestações identitárias portuguesas, apoiadas por formas retórico-discursivas próprias” (Cunha, 1998, p.66). 
África (São Paulo, 1978, Online), São Paulo, n. 42, p. 39-60, 2021

negação era não buscar influência das músicas portuguesas e procurar inspirações nas canções latino-americanas e congolesas, ou até mesmo no cinema americano e europeu. Ao mesmo tempo que o Ngola serviu de exemplo para surgir outros músicos e atrair mais pessoas na luta anticolonial, o grupo ganhava a rejeição dos colonos. Em uma sessão no Nacional Cine-Teatro, que era considerado o cinema dos brancos, o grupo chegou a ser hostilizado por muitos portugueses, em protesto que só encerrou quando o grupo deixou o palco, como retrata Santos (1999). Os gritos entoados eram para que eles voltassem para as suas aldeias de origem, uma vez que cantavam em quimbundo. Todavia, não eram apenas os portugueses que se incomodavam com o Ngola Ritmos. Em uma apresentação na Liga Nacional de Angola, os próprios angolanos expulsaram os músicos, acusando-os de "mussequeiros".

Os musseques eram realmente os locais onde os Ngola Ritmos tinham maior popularidade. Todavia, a maioria dos seus componentes morava no Bairro Operário. De acordo com Nascimento (2013), o Bairro Operário foi um local de grande concentração da luta anticolonial. Criado no início do Século XX, o bairro foi inicialmente um local de moradia de operários portugueses, o que justificava a origem do nome. Porém, por volta da década de 1940, houve uma intensa migração de famílias crioulas para o local, onde se concentraram na luta anticolonial, tanto no aspecto musical, como em outras ações políticas. Os integrantes do Ngola também formaram um grupo de nacionalistas para distribuir panfletos, alertando sobre a luta anticolonial, a partir de 1957. O fortalecimento do movimento anticolonial preocupou o império português, que instalou a Polícia Política Portuguesa (PIDE), a fim de investigar e cessar as movimentações, como ressalta Macqueen (1998). Com isso, ocorreram várias prisões e Liceu Vieira Dias foi um dos detidos. As prisões também aconteceram nas outras colônias portuguesas.

Lopes (2010) retrata que o campo de concentração de Tarrafal, em Cabo Verde, foi reaberto em 1961, para receber os nacionalistas das colônias portuguesas. Tarrafal foi marcado por mortes de comunistas e anarquistas nas décadas de 1930 e 1940. Na reabertura, músicos e escritores revolucionários das colônias estavam entre os presos e foram responsáveis por importante produção intelectual que representa a luta vivida em seus países. O líder do grupo Ngola Ritmos, Liceu Vieira, foi enviado para o campo de concentração de Tarrafal em 1962. O Ngola Ritmos continuou se apresentando em An- 
FRANCISCO CARLOS GUERRA DE MENDONÇA JÚNIOR A música como forma de resistência em Angola: Da música anticolonial ao rap de intervenção

gola, durante a prisão de seu líder, Liceu Vieira, que enviava algumas letras musicais para o grupo, utilizando estratégias que driblavam a segurança dos presídios. No Tarrafal, ele também passou a ser considerado o pai da música popular angolana, devido à projeção conseguida para mostrar em outros centros a causa da independência angolana.

Segundo Lopes (2010), durante a estadia em Tarrafal, outros intelectuais angolanos também exploraram a arte como forma de protesto. $\mathrm{O}$ médico Agostinho Neto foi um desses. Ele foi preso em 1960 e escrevia poesias a favor da independência do país e publicou três livros, além de ter sido lançada uma obra póstuma. Ele era presidente honorário do Movimento Popular Pela Libertação de Angola (MPLA), frente política que lutava pela independência do país, sendo enviado para vários presídios, incluindo Tarrafal, onde passou cerca de um ano e se aproximou de músicos angolanos, que compunham canções com viés revolucionário. A liberdade de Agostinho Neto foi concedida em 1963 e deve-se a pressões internacionais. Fora das cadeias, Agostinho foi morar na República do Congo e assumiu a presidência do MPLA.

\section{A música No PeRíOdo dA GUeRra ANTICOLONIAL}

O MPLA era uma das três frentes políticas que lutavam pela independência de Angola. Além desse movimento, ainda existiam no país a Frente Nacional de Libertação de Angola (FNLA) e a União Nacional para a Independência Total de Angola (Unita). As três frentes de libertação travaram uma Guerra Anticolonial contra o Império Português, a partir de 1961. Cada frente tinha maior abrangência em uma região do país e, consequentemente, também tinham as etnias que representavam. Porém, não era algo estritamente determinante, já que todas as frentes possuíam militantes nas diversas zonas do país. O FNLA tinha predominância no norte de Angola, onde a etnia que prevalecia era o bakongo e a língua era o kikongo. A Unita possuía maior abrangência na região centro-sul, local da etnia ovimbundo e da língua umbundu. Já o MPLA predominava na região central, onde fica a capital Luanda, na qual a etnia que prevalecia era o quimbundo e a língua também se chamava quimbundo. Nesse período, as frentes de libertação receberam apoios internacionais e apresentavam divergências entre si, tanto étni- 
África (São Paulo, 1978, Online), São Paulo, n. 42, p. 39-60, 2021

cas, como ideológicas. No quesito ideológico, as disputas refletiam o cenário de disputa internacional, ocorrido devido à Guerra Fria. Os Estados Unidos, França e África do Sul apoiaram a Unita. O MPLA recebeu suporte da União Soviética e de Cuba. Enquanto isso, o FNLA era apoiado pelo Congo Belga, atual República Democrática do Congo, além de ter recebido suporte por algum tempo de Romênia e China. Com o crescimento dos movimentos de libertação, a politização dos músicos também passou a ser cada vez maior, assim como a construção identitária das suas etnias. David Zé, Artur Nunes e Urbano de Castro passaram a cantar em prol de uma libertação liderada pelo MPLA. Eles se tornaram populares e impulsionaram o desejo de uma revolução anticolonial na população angolana.

O cunho político nas músicas dos três artistas é bastante perceptível. Além de vangloriar os ideais do MPLA, eles também enalteciam os seus líderes, com destaque para a figura de Agostinho Neto. Um exemplo é a música Revolução de Angola, de Urbano de Castro, em que é destacado o papel de Agostinho na luta pela libertação. Já David Zé tinha por opção cantar em língua quimbundo, sendo uma forma de contrapor a esse apagamento identitário e ainda realizar denúncias em locais públicos, que não eram entendidas pelos colonizadores (MACÊDO, MENESES, BIGAULT). Entre as canções de Artur Nunes, um exemplo de música com cunho político é a composição Ua ué mua Ngola, que passou a ser considerada uma espécie de hino pró-independência, pelo corpo militante do MPLA. Nessa letra, Artur Nunes denunciava os problemas sociais da colônia, mas anunciava que a independência estava por vir e iria garantir a liberdade total ao povo angolano (BIGAULT, 1999).

Além desses músicos que cantavam em prol dos ideais do MPLA, havia músicos que se identificavam com outras frentes de libertação. Por ter origem bakonga, Teta Lando era apontado como um porta-voz do povo do norte. Todavia, ele preferia um discurso de união e queda das bandeiras das frentes de libertação, ao invés de uma militância direta em prol do FNLA. Ele tinha um trauma político, que foi a morte do seu pai, em 1961, pelo regime salarazista. Com isso, Teta se transferiu para Lisboa, com apenas 13 anos (BIGAULT, 1999). Em Portugal, ele conheceu diversos músicos angolanos, como Rui Mingas, Vum Vum, Elias dia Kimuezu, Lilly Tchiumba e Bonga. Esses contatos, com artistas de várias etnias, influenciaram para que Teta Lando defendesse o 
FRANCISCO CARLOS GUERRA DE MENDONÇA JÚNIOR A música como forma de resistência em Angola: Da música anticolonial ao rap de intervenção

discurso da união de todos os povos, quando retornou para Angola em 1968. Nesse período, o músico encontrou um país com a luta pela libertação mais intensa e o número de artistas nacionalistas também em crescente.

Tanto o MPLA, como o FNLA, chegaram a lançar vinis com coletâneas dos seus músicos populares, enquanto a Unita não fez um trabalho musical próprio. A libertação das colônias africanas de Portugal, incluindo Angola, aconteceu após a Revolução dos Cravos, ocorrida em 25 de abril de 1974, quando membros do exército português se recusaram a viajar até as colônias, para prosseguirem com a Guerra, já que muitos soldados portugueses foram assassinados nos conflitos. FNLA, Unita e MPLA declararam independência, mas somente o MPLA teve reconhecimento. Assim, o líder do movimento, Agostinho Neto, proclamou a independência oficial de Angola em 11 de novembro de 1975, tornando-se o primeiro presidente de Angola em um regime monopartidário.

\section{A LIBERDADE CENSURADA PELO MPLA CONTRA MÚSICOS DO PRÓPRIO PARTIDO}

O regime monopartidário, implementado pelo MPLA, não foi aceito pelos grupos de oposição e uma Guerra Civil entre o MPLA e a Unita teve início em Angola desde 1975. O FNLA tornou-se apenas um apoiante da Unita nessa Guerra. Os ideais do MPLA continuaram sendo defendidos pelos músicos que apoiaram esse movimento durante os conflitos armados contra o Império Português. Urbano de Castro, David Zé e Artur Nunes passaram a atuar nas Forças Armadas Populares de Liberação de Angola (FAPLA), uma espécie de exército do MPLA. Com isso, eles formaram o conjunto musical Fapla-Povo, que acompanhou o presidente Agostinho Neto, em várias ações políticas, tanto em Angola, como fora do país. Outro coletivo musical, denominado Kisangela, foi formado pelo guitarrista e cantor José Agostinho e tinha uma série de músicos que se filiaram ao JMPLA (Juventude do MPLA). Eles reafirmavam nas letras o compromisso político com o MPLA e reforçavam os ideais do partido. O coletivo representou Angola em festas da independência de outras ex-colônias portuguesas.

Além dos conflitos com a Unita, a forma como o regime foi instituído fazia com que militantes do MPLA passassem a contestar o presidente 
África (São Paulo, 1978, Online), São Paulo, n. 42, p. 39-60, 2021

Agostinho Neto. De acordo com Mateus e Mateus (2007), a maior pressão interna aconteceu no dia 27 de maio de 1977, quando um grupo liderado por Nito Alves, que havia sido ministro do interior do governo de Agostinho Neto, liderou um movimento de contestação, que resultou na morte de Nito Alves, dos outros manifestantes e de mais pessoas que o governo entendeu como ameaças ao partido no poder ${ }^{3}$. Assim, foi ordenada uma chacina, em que as especulações do número de mortos oscilam entre 20 mil e 80 mil assassinados. Os populares músicos Urbano de Castro, Artur Nunes e David Zé estavam entre os mortos.

O caso até hoje é pouco investigado em Angola e ainda existem muitas dúvidas sobre quais motivos foram necessários para o massacre e quais as estratégias utilizadas. Mateus e Mateus (2007) afirmam que, após o massacre, o regime buscou silenciar todos os nichos que eram entendidos como possíveis locais de manifestação, em relação aos acontecimentos. Com o massacre do 27 de maio de 1977 e as mortes dos músicos, houve um silenciamento da música de intervenção em Angola, não sendo produzida qualquer canção de cunho político por vários anos no país. O medo foi instaurado entre os artistas que poderiam apresentar alguma forma de protesto, tanto no final do governo de Agostinho Neto, que deixou o poder ao falecer em 1979, como do seu sucessor, José Eduardo dos Santos. Apesar disso, ainda houve músicas politizadas no exterior feitas por angolanos.

Bonga é um dos pioneiros em protestar em prol de Angola no exterior. Ele iniciou essas manifestações ainda no período colonial. Em 1966, Bonga se transferiu para Portugal para treinar atletismo e se tornou um atleta de destaque. Apesar de defender Portugal em várias competições internacionais, Bonga sempre divulgava mensagens em favor do nacionalismo angolano nas comemorações das suas vitórias. Dessa forma, ele foi perseguido pela ditadura salazarista e fugiu para Holanda, onde iniciou a carreira profissional de

\footnotetext{
Nito Alves contestava as mudanças ideológicas do presidente. Agostinho defendia ideais marxistas-leninistas no período da luta pré-independência, afirmando que essa seria a ideologia política do partido, quando assumisse o poder. Todavia, depois de assumir o executivo, aceitava qualquer aliança política, com o intuito apenas de se manter no poder. $\mathrm{Na}$ insurreição do dia 27 de maio, o grupo liderado por Nito Alves tomou a Rádio Nacional de Angola, convocando a população para protestar em frente ao Palácio Presidencial, a fim de pressionar Agostinho Neto a cumprir os ideais iniciais do MPLA. O presidente primeiro adotou um discurso pacífico, durante as suas intervenções públicas no dia do ocorrido. Porém, no dia seguinte intitulara todos os manifestantes como fraccionários e agindo contra os ideais revolucionários, por isso, ordenou o assassinato de todos eles, afirmando que não iria perder tempo com julgamentos.
} 
FRANCISCO CARLOS GUERRA DE MENDONÇA JÚNIOR A música como forma de resistência em Angola: Da música anticolonial ao rap de intervenção

músico em 1972. Durante os primeiros anos de carreira, ele cantava em prol dos ideais do MPLA, tanto nos últimos anos da pré-independência, como depois da implantação do regime monopartidário. Todavia, depois de contestar alguns pontos do MPLA, o músico rompeu com o partido, passando a ser simpatizante da Unita. Ele gravou a música Zé Kitumba, em 1987, em analogia ao presidente José Eduardo dos Santos, afirmando que o mandatário enganava o povo. $\mathrm{Na}$ música, Bonga convoca a população para se manifestar, afirma que não é possível acreditar nas propostas do presidente e que ele deve ficar calado, após impor várias restrições de liberdade ao povo angolano. Por isso, ele canta no refrão: "Cala-te a boca Zé Kitumba, tu não pode reclamar". Bonga atualmente mora em Portugal, continua crítico ao regime do MPLA, mas sem ligações com a Unita.

Outro artista que apresenta há décadas contestação política fora de Angola é Paulo Flores. O cantor nasceu em Angola em 1972 e se mudou ainda criança para Portugal. Flores iniciou a carreira em 1988 e apresentou uma variabilidade de gêneros musicais, como semba e kizomba. $\mathrm{O}$ músico aborda temas do cotidiano, músicas dançantes e mensagens políticas, que pedem maior liberdade ao povo angolano. Ele passou a ser um dos nomes angolanos de maior referência pública fora do país. Em 2016, ele gravou a música Bajú, que é uma analogia aos "bajuladores", termo utilizado para definir as pessoas que são pagas para defender publicamente o MPLA.

\section{O CONTEXTO POLITICO DO SURGIMENTO DA MÚSICA RAP}

No ano de 1991, após 16 anos de Guerra Civil, o MPLA e Unita realizaram um acordo de paz. Para que fossem realizadas as negociações de paz, Folgôa (2002) relata que foi formada uma Troika, composta por Rússia, Portugal e Estados Unidos como intermediários. Em maio de 1991, os países fiscais se reúnem com Jonas Savimbi (líder da Unita) e José Eduardo dos Santos (presidente do MPLA e de Angola) e conseguem estabelecer um acordo de paz, que ficou conhecido como Acordos de Bicesse, devido ao nome da vila portuguesa onde se realizaram as negociações. Entre as medidas que foram determinadas, as principais foram o fim da Guerra Civil e a convocação das primeiras eleições multipartidárias em 1992, em que tiveram 
na disputa José Eduardo dos Santos pelo MPLA e Jonas Savimbi representando a Unita. O MPLA venceu o primeiro turno das eleições com $49 \%$ dos votos, enquanto a Unita recebeu $40 \%$. O resultado provocaria um segundo turno, mas a Unita, liderada por Jonas Savimbi, não aceitou o resultado e a Guerra Civil foi retomada.

O final da Guerra aconteceu apenas em 2002, após a morte do líder do Unita, Jonas Savimbi, em uma forte perseguição efetuada pelas Forças Armadas Angolanas. De acordo com Gonçalves (2004, p.24), foi uma "guerra civil predadora que abriu espaço a pesadas e custosas intervenções estrangeiras; ausência de política de desenvolvimento e colocação de Angola entre os mais baixos índices de desenvolvimento humano". Após o fim da guerra, também foram convocadas eleições presidenciais em 2002, 2012 e 2017, que garantiram a continuação do MPLA no poder.

Apesar de não terem sido determinantes para o fim da Guerra Civil, as primeiras eleições presidenciais em Angola, em 1992, possibilitaram mudanças no quadro social de Angola. A circulação de informações do país aumentou com o surgimento de veículos de comunicação privados, o que aumentou a possibilidade de críticas ao regime do MPLA. Além disso, Angola começou a sentir os efeitos da globalização. Outra consequência foi o primeiro contato de alguns jovens com a música rap, através do acesso de alguns álbuns desse gênero musical, oriundos dos Estados Unidos e da Europa. Esse contato possibilitou a produção de músicas locais nesse gênero, como retrata o rapper MCK (2016) ${ }^{4}$.

Com a transição de 1991 (...) conquistamos algumas liberdades. Era uma democracia embrionária a emergir. Mas, entretanto, a carga repressiva do partido único reduziu significativamente (...) e isso abriu vários passos que proporcionaram essa liberdade que o rap ganhou. Por exemplo, ganhamos mais jornais. Deixamos de ter um único meio oficial, que era a televisão pública e o jornal. Foi nessa altura que surgiram os Folha 8, o Agora, o Atual, a nível de imprensa alargamos um bocadinho o leque. Começamos a tomar maior contato com o fenômeno globalização, a internet e etc. E determinadas práticas repressivas tinham que ser feitas ou na clandestinidade com maior cuidado ou deixar de ser feitas publicamente, porque a denúncia começou a entrar na equação Angola variável dos direitos humanos, do

$4 \quad$ Entrevista realizada em 2016, em Lisboa. 
FRANCISCO CARLOS GUERRA DE MENDONÇA JÚNIOR A música como forma de resistência em Angola: Da música anticolonial ao rap de intervenção

respeito a cidadania, do respeito aos direitos (MCK, entrevista, 04 de dezembro de 2016).

O primeiro grupo de rap que este trabalho obteve registro foi GC Unity, atuante desde o final da década de 1980, que não chegou a obter grande sucesso público. $\mathrm{O}$ impulsionamento da música rap ocorre com o grupo SSP, surgido inicialmente na antiga Alemanha Oriental e atuante em Angola desde 1992. Esse grupo compunha músicas dançantes e voltadas para festas, sem qualquer crítica social. Nos anos seguintes, surgiram jovens que compuseram músicas retratando sobre questões do cotidiano, como problemas em suas ruas, mas ainda sem um grande aprofundamento político, até mesmo porque a maioria dos rappers ainda era adolescentes.

\section{O RAP COMO MEIO DE CRÍTICAS SOCIAIS EM ANGOLA}

O grupo Filhos D’ala. Este é considerado pioneiro na composição de músicas rap com forte teor político. A partir daí, inicia-se um confronto direto dos membros do movimento hip-hop, do qual a música rap faz parte, com o regime político angolano. Além desse grupo, o rapper MCK destaca o surgimento de outros coletivos musicais, criados em um terreno propício para essas críticas: "A música como uma ferramenta de despertar consciências é retomada no movimento hip-hop, com grupos com os Filhos D'Ala Leste, os Pobres Sem Culpa, Mutu Moxi e muitas outras referências" (MCK, entrevista, 05 de dezembro de 2016).

MCK já era um participante do movimento hip-hop, mas só passou a realizar críticas sociais, ao observar outros artistas também o fazendo. Assim, considera que ganhou energias com o momento e lançou o disco Trincheira de Ideias, em 2002. O álbum ganhou grande repercussão entre os jovens e o lavador de carros Arsénio Sebastião, o Cherokee, foi assassinado por guardas da Unidade de Guarda Presidencial (UGP), afogado em praça pública, por ter reproduzido a música intitulada de A Téknica, as Kausas e as Konsekuencias em uma caixa de som, enquanto trabalhava, lavando os carros no centro de Luanda.

Foi um momento de muita tensão, obviamente. Não só pressão a nível de instituições, mas também pressões a nível familiar. $\mathrm{Na}$ minha família, como na 
família do "Cherokee", porque foi uma vida que se foi embora. Mas também foi um marco muito importante na minha carreira, porque eu deixei de ser um mero artista, um mero rapper e passei a ser um ativista cívico. Passei a ser nesse momento defensor dos direitos humanos. Isso provavelmente foi a coisa que me galvanizou a continuar e não parar. (...) Mais do que isso, o assunto, por ser uma agressão ao mais humilde dos direitos, que é o direito à vida, teve uma repercussão internacional muito forte. (...) Então, ao invés de estimular a parar, deu energias e galvanizou-me a continuar. Mais do que isso, deu-me um sentido orientador a minha carreira (MCK, entrevista, 07 de dezembro de 2016).

Devido a esse fato, o rapper Ikonoklasta ${ }^{5}$ resolveu gravar uma música em que expõe com ainda mais contundência as opressões do regime angolano, em canção intitulada como Sou um kamikaze angolano e essa é minha missão. Ele escreve a letra como sendo a sua carta de despedida, faz saudações as pessoas que ama, mas afirma não aguentar mais o silenciamento. Por isso, adianta que será a última música dele, pois o regime costuma matar os seus divergentes. Ainda assim, ele precisaria relatar os problemas sociais constatados, como última ação em vida.

Apesar de ser um crítico do regime do MPLA, Ikonoklasta é filho de um ex-dirigente do primeiro escalão do governo de José Eduardo dos Santos, o engenheiro João Beirão. O pai de Ikonoklasta coordenava a Fundação José Eduardo (FESA), criada para enaltecer a imagem do então presidente. O privilégio financeiro da família do artista permitiu que ele tivesse acesso à educação na Europa, onde frequentou universidades na França $\mathrm{e}$ na Inglaterra. Todavia, o músico utiliza o conhecimento sobre a política angolana, para contrariar justamente os interesses que seu pai defendia. Como é constantemente acusado de ser um "filho de regime", ele afirma que, por ter sido beneficiado em estudar no exterior, não o obriga a ser defensor das ideias do pai.

Outro artista que critica o regime é Ngola Sambela, que adotou o nome artístico de Flagelo Urbano. Ele trabalha como advogado e professor universitário, buscando não ter dependência financeira do rap, pois acredita que a independência monetária garante a integridade da mensagem.

\footnotetext{
$5 \quad$ Nome artístico do conhecido ativista cívico Luaty Beirão.
} 
FRANCISCO CARLOS GUERRA DE MENDONÇA JÚNIOR A música como forma de resistência em Angola: Da música anticolonial ao rap de intervenção

\begin{abstract}
A opção por manter uma postura independente, fora dos principais eixos do mercado, se deve ao fato de buscar manter com a minha integridade intelectual. Em Angola, é muito difícil conseguir ter alguma rentabilidade, se o artista não atender aos interesses do partido no poder. Por isso, mantenho a minha postura, trabalhando como advogado, buscando minhas rendas através disso e atualmente cursando o mestrado em direito (FLAGELO URBANO, depoimento via whatsapp, 25 de abril de 2017).
\end{abstract}

Além disso, há rappers angolanos que devido às perseguições políticas foram se exilar na França, como Simão França, que se mudou para aquele país em 2008. Brigadeiro 10 Pacotes também esteve exilado na França entre 2013 e 2020. Mesmo morando na França, 10 Pacotes esteve recolhendo assinaturas para formar um partido político em Angola, denominado Os Crentes. Ao retornar para Angola, continuou buscando assinaturas em várias províncias. Mesmo que não consiga formalizar o partido, o grupo político Os Crentes deve construir uma aliança com o Bloco Democrático nas eleições presidenciais de Angola em 2022. Lança (2010) aponta outros nomes como Kheita Mayanda, Phay Grande, Leonardo Wauiti e Condutor, como uma geração "que traduz as preocupações da nova geração que habita no centro e na periferia de uma cidade globalizada". Existe também várias artistas mulheres, que buscam trabalhar em prol do rap feminista em Angola. Entre elas, as mais populares são Meduza, MAMY, Eva Rap Diva e Vanda Mãe Grande.

\title{
MEMÓRIAS DAS LUTAS HISTÓRICAS RESGATADAS PELO RAP
}

Apesar de o hip-hop ser um movimento contemporâneo e a maioria dos seus militantes ser jovens, os rappers buscam fazer um resgate histórico das lutas passadas em Angola. Lázaro e Silva (2016, p.59) citam como exemplo, a música 27 de maio, do rapper Baxaxa, que retrata sobre a memória dos mortos da chacina de 1977. MCK (2017) afirma, em entrevista, até o material didático esconde os episódios mais contraditórios da história de Angola. Com isso, os rappers cumprem esse papel de repassar a história de luta dos antepassados.

Uma forma de homenagem é através da regravação de músicas que marcaram época, como fazem o rapper Ikonoklasta e a cantora Aline Frazão, 
África (São Paulo, 1978, Online), São Paulo, n. 42, p. 39-60, 2021

ao cantarem a música $O$ que eu quero, de André Mingas. $\mathrm{O}$ cantor homenageado morreu em 2011 e gravou a canção na década de 1970. Ele apresenta um tom de esperança no futuro de Angola e a busca por alegria, assim como qualquer outro jovem, que pode ser readaptada para a luta da atualidade. André Mingas é sobrinho do fundador do Ngola Ritmos, Liceu Vieira Dias.

$\mathrm{O}$ rapper MCK e o cantor Paulo Flores também fizeram uma homenagem ao grupo Kiezos, ao realizarem uma readaptação da música Nzala, dos Kiezos, que varia entre a utilização do português e do quimbundo. Os Kiezos apresentavam uma linguagem codificada contra os colonos, pois utilizava gírias das línguas locais para criticar o governo. Eles criavam composições em ritmos dançantes, que faziam os colonizadores bailarem, por não entenderem as críticas que estavam recebendo nas letras. No videoclipe, lançado em 2013, são apresentadas imagens em animação, que remetem a assassinatos e abusos de poder realizados pelo regime angolano.

\begin{abstract}
. (Nzala) É uma readaptação de uma música dos Kiezos, que é uma figura importante da música angolana. Nzala é uma palavra em quimbundo, que quer dizer fome e nós cantamos a mesma coisa passados 20 anos depois e com a mesma contundência. De um modo geral, as nossas músicas, mesmo as que não me lembro, marcam profundamente (...) tem sempre um significado muito forte. $\mathrm{O}$ ritmo remonta uma fase importante da história de Angola. (...) Esse grupo no passado tem um selo de respeitabilidade, por cantar em um dialeto local. Os portugueses não percebiam. Eles eram uma espécie de bobo da corte. Eles faziam os portugueses dançar, a cantarem numa língua que eles não estavam a entender, que a mensagem era não nos queremos aqui, vão embora (MCK, entrevista, 18 de fevereiro de 2017).
\end{abstract}

O rapper MCK também possui parcerias com o músico Beto de Almeida nas canções Atrás do Prejuízo e Por Detrás do Pano. Essa última também possui participação de Ângela Ferrão. Beto de Almeida faleceu em 2013, por isso, o rapper homenageou o cantor na música Condolências. $\mathrm{Na}$ letra, são utilizados trechos cantados por Beto de Almeida, fazendo a utilização de samples ${ }^{6}$. Os samples são usados com frequência no rap angolano, para

\footnotetext{
De acordo com Tordjman (1998), o sample é um recurso utilizado pelos produtores de rap, em que é feita uma extração de trechos de músicas, sequências melódicas ou até mesmo discursos ou sons não musicais, para fazerem parte de uma música de rap. O sample pode servir para ser colocado em um trecho da música ou mesmo ser utilizado como instrumental de uma nova música.
} 
FRANCISCO CARLOS GUERRA DE MENDONÇA JÚNIOR A música como forma de resistência em Angola: Da música anticolonial ao rap de intervenção

remeter o passado de luta de artistas que foram mortos ou silenciados, por combaterem opressões ao longo da história da música angolana.

O rapper Flagelo Urbano produziu o disco coletivo Reunir, no qual convidou vários rappers para realizarem homenagens a Teta Lando, ressaltando a importância do músico, para as novas gerações da música angolana. O disco foi lançado em 2010, dois anos depois da morte do músico bakongo e foram feitas regravações de músicas de Teta Lando ou samples de canções, para a criação de novas composições. Foram convidados 17 artistas ligados aos rap, para participarem do álbum. Em seus trabalhos individuais, Flagelo Urbano também conta com homenagens históricas. O EP Entre o Tempo e a Memória, de 2009, é marcado por samples de vários músicos angolanos. Já o álbum $O$ Ermo, de 2015, utiliza os recursos instrumentais de músicos de outros países africanos.

O Conjunto Ngonguenha foi formado em 2002, como um grupo de rap focado em referenciar os gêneros musicais existentes em Angola nas décadas de 1960 e 1970, período em que as bandas locais eram intituladas de conjuntos. Dessa forma, o Ngonguenha resgata essa nomenclatura para um grupo de rap e faz uma mescla com os gêneros musicais das décadas de 1960 e 1970, além de resgatar a musicalidade de ritmos mais recentes, como o kuduro. O Conjunto realizava samples de vários artistas, a exemplo de Artur Nunes, que teve a música Tia sampleada pelo grupo, em música com título homônimo. A música Tia também foi sampleada por Phay Grande, o Poeta, na música Povo Burro. MCK já prestou homenagens a dezenas de músicos angolanos em suas composições e considera que há uma continuação do espírito de transformação de consciências por intermédio da música. Por regra geral, os artistas sampleados lutaram nas décadas de 1960 e 1970, para combater o regime opressor colonial. Atualmente, a luta é contra a opressão feita pelo regime de angolanos, mas o rapper MCK observa uma sensação de continuidade de lutas, pelo fato de a música ser vista como ferramenta de transformação, em ambos os momentos, mesmo com objetivos diferentes.

Os samples de músicos de Angola não se restringem a produções locais. O rapper norte-americano Nas e o regueiro jamaicano Damian Marley (filho de Bob Marley) fizeram um sample da música de David Zé Uendengue Uami. A música Friends, dos artistas famosos internacionalmente, inicia com um trecho de Uendegue Uami e o restante da sequência rítmica instrumental é 
África (São Paulo, 1978, Online), São Paulo, n. 42, p. 39-60, 2021

toda feita através de uma estratificação da canção do angolano, que foi assassinado no dia 27 de maio de 1977. Uendengue Uami faz analogia a história de vida de David Zé, em paralelo com a história da nação. O rapper angolano MCK já havia sampleado a música, em 2002. Ele utilizou trecho da música de David Zé na música Políticas de Domínio.

\section{A PARTICIPAÇÃO DE RAPPERS EM MANIFESTAÇÕES DE RUA EM ANGOLA}

A participação de rappers em manifestações sociais de rua inicia em 2011, quando Ikonoklasta passou a considerar insuficiente as ações apenas no âmbito musical e resolveu convocar as pessoas para manifestarem-se nas ruas. Beirão foi convidado para participar de um show do rapper angolano Bob da Rage em 27 de fevereiro de 2011 e soube que um filho do então presidente do país José Eduardo dos Santos estaria na plateia, por isso, preparou um protesto específico para ele. Eduane Danilo dos Santos era o filho do presidente que estava no público. Ikonoklasta expôs uma faixa com os dizeres "Ti Zé tira o péTô prazo expirou há bwé!". Esse cartaz denotava um desejo de que José Eduardo dos Santos saísse do poder, que assumiu em 1979. Além disso, Ikonoklasta deixou o aviso para "papá" de que "Não queremos mais ele aqui. 32 é muito. É muito!". Ikonoklasta ainda convocou todo o público, formado por cerca de três mil pessoas, para o primeiro protesto de rua a ser realizado no país, desde o 27 de maio de 1977. O protesto ocorreu em 07 de março de 2011 e contou com pouco mais de uma dezena de manifestantes e 12 pessoas foram presas, incluindo o próprio Ikonoklasta e jornalistas. Outro rapper presente na manifestação de março de 2011 foi Carbono Casimiro, que faleceu em 2019, por consequência da falta de estrutura do sistema de saúde do país. Os ativistas continuaram realizando manifestações e o regime respondeu aumentando as repressões. Prisões, proibições das ações e violências policiais tornaram-se constantes nas ações ou tentativas de manifestações desses ativistas.

Em 27 maio de 2012, os ativistas Alves Kamulingue e Isaías Cassule desapareceram, após uma tentativa de manifestação. Em novembro de 2013, o Ministério do Interior assumiu as mortes deles, em um documento secreto, em que revelava detalhes dos assassinatos, como o fato de Kamulingue ter sido assassinado com um tiro na cabeça e o corpo ter sido abandonado em 
FRANCISCO CARLOS GUERRA DE MENDONÇA JÚNIOR A música como forma de resistência em Angola: Da música anticolonial ao rap de intervenção

uma mata fora de Luanda, enquanto Isaías Cassule teria sido espancado por dois dias seguidos e teria sido arremessado no rio.

Devido às diversas restrições, os ativistas cívicos passaram a se reunir de forma secreta, para planejar futuras ações. Todavia, em 20 de junho de 2015, 15 ativistas foram presos, por estarem debatendo o livro Ferramentas para destruir o ditador e evitar uma nova ditadura. Filosofia política da libertação para Angola, de Domingos da Cruz (2015). Entre os presos, estavam o autor do livro e o rapper Ikonoklasta. Além disso, as ativistas Rosa Conde e Laurinda Gouveia também foram presas posteriormente, por se pronunciarem publicamente sobre o caso, que passou a ser conhecido como $15+2$. $\mathrm{O}$ acontecimento ganhou repercussão durante a greve de fome de Ikonoklasta, que passou 36 dias sem se alimentar, entre setembro e outubro de 2016, protesto realizado devido ao excesso de prisão preventiva. $\mathrm{O}$ caso ganhou repercussão internacional e o governo angolano passou a receber pressão de entidades como a Organização da Nações Unidas e a Anistia Internacional. Luaty Beirão, o Ikonoklasta, foi quem teve o nome mais repercutido durante a prisão, por ter nacionalidade portuguesa e, assim, houve muita pressão da mídia, para que Portugal interferisse nessa violação dos direitos humanos. Os ativistas foram soltos em 29 de junho de 2016.

A repercussão da prisão dos ativistas fez com que eles fossem convidados para divulgar o cenário político de Angola em outros países, como Holanda, Brasil, França e Portugal. Ikonoklasta foi quem recebeu mais convites, como uma audiência pública no Parlamento Europeu e ainda palestras para a Anistia Internacional e a ONU. Além disso, ele lançou dois livros: Sou eu mais livre, então, que é um diário feito na cadeia, lançado ainda em 2016, e Kanguei no Maiki, que apresenta a compilação das letras do artista e foi publicado em julho de 2017. As retaliações continuaram no país, após a soltura, tanto no quesito artístico, como nas manifestações. Luaty Beirão teve várias autorizações para realizar shows negadas, até conseguir realizar o seu primeiro show depois que saiu da cadeia. Em um dos episódios em que o show quase foi realizado, ocorrido em novembro de 2016, houve uma autorização inicial, mas os policiais alegaram a falta de algumas licenças, para proibir poucos minutos antes. A primeira apresentação depois de Luaty Beirão sair da cadeia só aconteceu em março de 2017, na sede da Rádio Despertar, pertencente a Unita, que improvisou um palco em seu espaço para garagem de veículos. 
África (São Paulo, 1978, Online), São Paulo, n. 42, p. 39-60, 2021

O cenário atual: As liberdades após a saída de José Eduardo dos Santos

No dia 23 de agosto de 2017, foram realizadas as últimas eleições presidenciais em Angola. José Eduardo dos Santos optou por não se candidatar novamente ao cargo, alegando saúde debilitada. Porém, sabe-se que as pressões populares e internacionais contribuíram para que o político desistisse da candidatura. $\mathrm{O}$ caso $15+2$ foi determinante para essas pressões políticas. Em seu lugar, o MPLA indicou João Lourenço, que venceu o pleito. Apesar de não se candidatar novamente ao cargo que ocupava desde 1979, José Eduardo dos Santos conseguiu aprovar, dois meses antes de sua saída, uma legislação que o blindava perante a justiça. Essa lei garante que todos os ex-presidentes continuem como presidente emérito do país e tenham privilégios, como a manutenção dos salários e a impunidade ${ }^{7}$ Na prática, é uma lei apenas para José Eduardo dos Santos, único ex-presidente ainda vivo.

O pleito eleitoral também foi repleto de contradições. A Comissão Nacional Eleitoral anunciou a vitória do MPLA por maioria absoluta. Todavia, a oposição e um grupo de fiscais voluntários questionaram esses números. A acusação é de que esses dados foram decididos pelo próprio MPLA, sem uma apuração rigorosa. A Unita e um grupo denominado Jiku realizaram contagens paralelas. O Jiku, que conta com vários rappers, incluindo Ikonoklasta, realizou a contagem através de fiscais voluntários que enviaram as atas das assembleias eleitorais. Com o resultado apurado pelo Jiku, o MPLA continuaria vencendo as eleições, mas não teria maioria absoluta no congresso, já que Casa-CE e Unita somam juntos mais votos do que o MPLA. Por conta disso, a oposição chegou a ameaçar não tomar posse dos cargos, bem como tentaram impugnar o pleito ${ }^{8}$. Como não conseguiram, tomaram posse e alegaram que seria o melhor caminho para combater a corrupção e lutar por uma efetivação da democracia.

Apesar desse quadro problemático, Angola tem apresentado melhorias em termos de liberdades no mandato de João Lourenço. O presidente exo-

\footnotetext{
Disponível em: https://www.dn.pt/mundo/jose-eduardo-dos-santos-deixa-poder-mas-com-imunidade-subvencao-vitalicia-e-casa-oficial-8713440.html. Acesso em 29 de agosto de 2021.

8 Disponível em: https://www.voaportugues.com/a/oposicao-aposta-impugnacao-eleicoes-mpla-respeito/4016187.html. Acesso em 29 de agosto de 2021.
} 
FRANCISCO CARLOS GUERRA DE MENDONÇA JÚNIOR A música como forma de resistência em Angola: Da música anticolonial ao rap de intervenção

nerou todos os filhos de José Eduardo dos Santos de cargos no governo, com destaque para os canais públicos de comunicação. Em seu discurso de posse, João Lourenço reconheceu que as liberdades de expressão e de imprensa seriam desafios a serem enfrentados em sua gestão, reforçando que não existe democracia efetiva sem essas liberdades'.

Em relação especificamente a música, o rapper Ikonoklasta foi um dos convidados para reunião com o presidente em sessão especial, para conversarem sobre os problemas políticos do país ${ }^{10}$. Ademais, o rapper $\mathrm{MCK}$ informou que não houve mais proibições aos seus shows e ainda tem ocorrido convites inéditos para programas em canais públicos, para ele e para outros rappers. Por outro lado, houve algumas detenções, como os rappers Cheick Hata e Jaime MC, que estiveram presos por um dia, após protestarem contra a falta de água no bairro Cacuaco em 2020". Porém, a polícia justificou que as prisões foram motivadas por desobediência as regras de isolamento obrigatórias no período de pandemia do Covid-19 e não por repressão a protestos.

\section{CONCLUSÕES}

O conteúdo apresentado neste artigo possibilita comprovar a importância da música, como impulsionadora de mudanças sociais, a partir do estímulo a manifestações sociais do passado e do presente, impulsionadas por pioneiros como o Ngola Ritmos no período da luta anticolonial e Ikonoklasta no chamado a manifestações de rua contemporâneas. Foi por meio da música que a sociedade angolana pôde ser informada, no período anticolonial e na atualidade, sobre análises políticas que deveriam estar em relatórios públicos ou materiais didáticos. Porém, os meios formais são estrategicamente postos para silenciar a pluralização de ideias e esconder as contradições políticas do país.

9 Disponível em: https://www.noticiasaominuto.com/mundo/899899/nao-ha-democracia-sem-liberdade-de-expressao-semliberdade-de-imprensa. Acesso em 12 de março de 2019.

10 Disponível em: https://www.publico.pt/2018/12/04/mundo/noticia/rafael-marques-luaty-beirao-serao-recebidos-terca-presidente-angola-1853401. Acesso em: 18 de junho de 2019.

11 Disponível em: https://undergroundlusofono.com/2020/08/apos-manifestacao-por-falta-de-agua-rappers-ativistas-angolanos-estiveram-presos-por-dois-dias/. Acesso em: 08 de agosto de 2020. 
África (São Paulo, 1978, Online), São Paulo, n. 42, p. 39-60, 2021

A resistência política pode acontecer com mensagens diretas, proferidas em músicas como as mensagens reivindicativas de artistas como Artur Nunes ou MCK, bem como por meio de um resgate identitário, como a utilização de ritmos e línguas locais. Trata-se de um resgate identitário fundamental para se manter a memória viva daqueles historicamente silenciados, mas qualquer resgate sempre aquém dos apagamentos, devido ao genocídio que destruiu etnias inteiras e extinguiu diversos hábitos, costumes, saberes e línguas. Nesse resgate, o sample de músicas do passado é fundamental para se manter a história viva e estimular o povo angolano a entender o legado histórico de revolucionários do passado, para serem incentivados a continuarem lutando por mudanças políticas na atualidade.

\section{REFERÊNCIAS BIBLIOGRÁFICAS}

ALVES, A. P. Angola: musicalidade, política e anticolonialismo (1950 - 1980). In: Tempo \& Argumento. Santa Catarina: Udesc, vol.5, número 10: 373-396, 2013.

BEIRÃO, L. Sou eu mais livre, então. Lisboa: Tinta da China, 2016.

BEIRÃO, L. Kanguei no maiki. São Paulo: Demônio Negro, 2017.

BIGAULT, A. Antologia das músicas de Angola. Ivry-sur-Seine: Buda Music, 1990.

CRUZ, D. Da ditadura a democracia - Ferramentas para destruir a ditadura e evitar novo ditador. Lisboa: Tinta da China, 2015.

CUNHA, I. F. Lusotropicalismo, racismo e identidade. In Revista Brasileira de Ciências da Comunicação, vol. 21, n 1. São Paulo, 1998.

FIGUEIREDO, L. Sita Valles: Revolucionária, comunista até à morte. Lisboa: Alêtheia Editores, 2014.

FOLGÔA, C. O caso peculiar das relações em Angola. In Janus Online. Lisboa: Observatório de Relações Internacionais - Universidade Autônoma de Lisboa, 2002.

GONÇALVES, J. O descontínuo processo de desenvolvimento democrático em Angola. In Occasional Papers. Lisboa: Centro de Estudos Africanos, ISCTE, 2004.

LANÇA, M. Luanda está a mexer! Hip hop underground. In Buala.org, 2010.

LOPES, J. V. Tarrafal - Chão Bom - Memórias e Verdades (II Volumes). Praia: Instituto de Investigação e Patrimônio Culturais, 2010.

MACÊDO, T. Luanda, cidade e literatura. São Paulo: Editora Unesp, 2008. 
FRANCISCO CARLOS GUERRA DE MENDONÇA JÚNIOR A música como forma de resistência em Angola: Da música anticolonial ao rap de intervenção

MACQUEEN, N. A descolonização da África portuguesa: a revolução metropolitana e a dissolução do império. Lisboa: Editorial Inquérito, 1998.

MATEUS, D.C. \& MATEUS, A. Purga em Angola. Nito Alves, Sita Valles, Zé Van Dunem e o 27 de maio de 1977. Lisboa: Edições Asa, 2007.

MENESES, M. P. O 'indígena' africano e o colono 'europeu': A construção da diferença por processos legais. In E-cadernos CES. Coimbra: CES, 2010.

MORMAAN, M. Música e lusotropicalismo na Luanda colonial tardia. Tradução: H. Rita. In Buala.org, 2010.

NASCIMENTO, W. S. Gentes do Mato: “Os novos assimilados” em Luanda (1926-1961). Tese de Doutorado. São Paulo: USP, 2013.

LÁZARO, G. \& SILVA, O. Hip-hop em Angola: O rap de intervenção social. In: Cadernos de Estudos Africanos. Lisboa: ISCTE-IUL, 2016.

SANTOS, J.A. ABC do Bê Ò. Luanda: Edições CC, 1999.

TORDJMAN, G. Sept remarques pour une esthétique du sample. In Technikart. vol. 20. 1998. 